\title{
THE ROLE OF TRUST-BASED ACTIVE PARTICIPATION AS A LEARNING MEDIATION CONCEPT FOR LEVERAGING THE IMPACT OF INFORMATION TECHNOLOGY ON CREATIVE PERFORMANCE
}

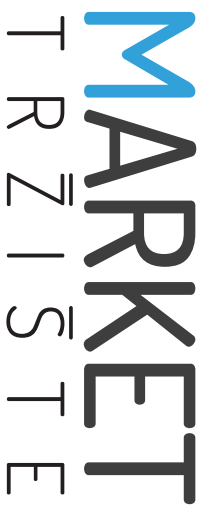

\section{ULOGA AKTIVNOG SUDJELOVANJA TEMELJENOG NA POVJERENJU KAO MEDIJATORA UČENJA ZA UPOTREBU INFORMACIJSKE TEHNOLOGIJE ZA KREATIVNE IZVEDBE}

Market-Tržište

Vol. 32, No. 2, 2020, pp. 221-235

UDK 004:65.011.8:005.64

DOl http://dx.doi.org/10.22598/mt/2020.32.2.221

Preliminary communication

\begin{abstract}
Iwan Hermawan ${ }^{a}$, Suharnomo ${ }^{b}$
a Universitas Diponegoro, Economic and Business Department, Prof. Soedharto, Semarang, INDONESIA, e-mail: iwanpolines@gmail.com

b Universitas Diponegoro, Economic and Business Department, Prof. Soedharto, Semarang, INDONESIA, e-mail: suharnomo@ undip.ac.id
\end{abstract}

\begin{abstract}
Purpose - While information technology (IT) has an important role in organizational development nowadays, in many previous studies, it was not found to have a significant direct effect on performance, thus producing a gap. The novelty of this study lies in building a conceptual model aimed at explaining the inconclusive gap research. Information technology in its capacity as infrastructure has the role of providing knowledge induction support to organizations, thus providing another dynamic concept, one of which is learning. In many previous studies, researchers completed the inconclusiveness gap of this research by using an approach derived from the organizational learning $(\mathrm{OL})$ theory. However, this leaves a new inconclusiveness because the gap cannot be resolved just by ordinary organizational learning
\end{abstract}

\section{Sažetak}

Svrha - Informacijska tehnologija (IT) danas zauzima važnu ulogu u organizacijskom razvoju, ali u mnogim prethodnim istraživanjima nije pokazala značajniji izravan utjecaj na učinkovitost. Time je stvoren istraživački jaz. Novost ovog istraživanja jest izgradnja konceptualnog modela koji može objasniti prazninu u istraživanju. Informacijska tehnologija u svojstvu infrastrukture ima ulogu potpore poticanju znanja $u$ organizacijama kroz dinamični koncept, od kojih je jedan učenje. U mnogim prijašnjim studijama istraživači su popunili prazninu koristeći pristup izveden iz teorije organizacijskog učenja (OL), no još uvijek postoje nedorečenosti jer se ovaj jaz ne može riješiti samo uobičajenim organizacijskim učenjem, već se odnosi na koncept kohezivnog nesvjesnog učenja. Kohezivni 
but refers to a concept of tacit, cohesive trust-based learning. The cohesive concept is intended to dynamize the organizational learning process.

Design/methodology/approach - The sample is a design-based fashion SME that has been established for a minimum of three years, the SME business line is relevant to the variables displayed because SMEs face strong demands to build their knowledge by getting brilliant ideas to continue to survive in a creative industry. The analytical tool used is Structural Equation Modeling (SEM).

Findings and implication - The results of analysis build on the equation $\mathrm{CP}=0.599 \mathrm{IT}+1.524 \mathrm{TBAP}-0.288 \mathrm{RTC}$. They provide empirical evidence that trust-based active participation (TBAP) has succeeded in becoming a full mediator that has a significant influence on the role of IT, $\beta$ $=0.96, p<0.001$ on creative performance $(C P) \beta=1.70$, $p<0.001$. This paper fills the body of knowledge in the domain of organizational learning with trust-based active participation as a concept novelty.

Limitation - While the value of AGFI 0.869 is smaller than cut off (0.90), that figure is still considered fit.

Originality - This paper offers TBAP as a novelty in trying to fill the research gap. Value trust is inherent in teamwork within mutual learning induction organizations, where trust is presented to highlight cohesiveness in teamwork and the understanding that team members are not competitors. In the future, they will create a safe zone of sharing in learning, this condition will in turn encourage tacit knowledge, mastered by the members which can be shared in teams as repositories of organizational knowledge.

Keywords - information technology, trust-based active participation, creative performance koncept namijenjen je dinamiziranju procesa organizacijskog učenja.

Metodološki pristup - Uzorak čine zaposlenici malog-srednjeg poduzeća iz dizajnerske-modne industrije koje posluje najmanje tri godine. Izabrano je zbog toga što je relevantno za prikazane varijable te zbog velike potrebe za izgradnjom znanja za dobivanje izvrsnih ideja radi opstanka u kreativnoj industriji. Korišteni analitički alat jest modeliranje strukturnih jednadžbi (SEM).

Rezultati i implikacije - Analiza rezultata predlaže jednadžbu $C P=0.599 \mid T+1.524 T B A P-0.288 R T C$. Rezultati istraživanja pružaju empirijske dokaze da je TBAP uspio postati potpuni medijator sa značajnim utjecajem uloge informacijske tehnologije IT $\beta=0,96, p<0,001$ na kreativnu izvedbu (CP) $\beta=1,70, p<0,001$. Rad dopunjuje znanja iz područja organizacijskog učenja novim konceptom aktivnog sudjelovanja temeljenog na povjerenju.

Ograničenja - lako je vrijednost AGFI 0,869 manja od granične vrijednosti $(0,90)$, još uvijek se smatra prikladnom.

Doprinos - Rad nudi novi koncept, sudjelovanje temeljeno na povjerenju (TBAP) kao odgovor na jaz u prijašnjim istraživanjima. Vrijednosno povjerenje svojstveno je timskom radu unutar organizacija u kojima je prisutno uzajamno učenje, gdje se povjerenjem naglašava kohezija i razumijevanje timskog rada tako da članovi tima nisu međusobni konkurenti u budućnosti. To će stvoriti sigurnu zonu dijeljenja pri učenju; stanje će potaknuti nesvjesno znanje članova koji se mogu dijeliti u timove kao spremišta organizacijskog znanja.

Ključne riječi - informacijska tehnologija, aktivno sudjelovanje temeljeno na povjerenju, kreativna izvedba 


\section{INTRODUCTION}

Process learning is part of the organization's need to survive because organizations always want to learn, thus it becomes the backbone of organizational knowledge to create a competitive advantage. The concept of organizational learning $(\mathrm{OL})$ has been adopted by many researchers (Cuevas-Vargas, Estrada \& Larios-Gómez, 2016; Rasel, 2016; Sancez, Milan \& Sahuquillo, 2018; Torkestani, Mazloomi \& Haghighat, 2014; Yunis, Tarhini \& Kassar, 2018) and has become the central concept for activating the knowledge infrastructure in organizations, and one of the essential knowledge infrastructure resources is information technology (IT). IT in the context of resource-based view (RBV) is a static instrument in an organization. As an infrastructure, IT will conventionally correlate to concepts derived from dynamic theories, which aim to develop organizational innovation. Within the RBV framework, IT needs to be dynamic by cooperating with other concepts such as $\mathrm{OL}$ to produce innovation (Kim \& Lee, 2006); the ability to create innovation with the agility of capturing knowledge in a collective learning will be facilitated by the presence of IT (Hashim \& Tan, 2015; Kim \& Lee, 2006). Furthermore, the elaboration of knowledge and technology will foster a climate of creativity in organizations. According to other studies (Tippins \& Sohi, 2003), the way an organization fosters creativity is by focusing on the learning processes that are disseminated to all organizational entities.

Unlimited trade is changing the face of the economy today. In Indonesia, there are $\mathbf{2 7 0}$ million people with a technology literacy rate of 64.8\% (APJII, 2018), representing the awareness of Internet usage by Indonesian people. This fact paves the way for the opening of the digital business market potential in Indonesia. The role of IT within Indonesian organizations, starting from that of a supporting tool, has now evolved into an organizational strategic tool because of the Internet flourishing (Hermawan, Sartono \& Khakim, 2016; Matin \& Sabagh, 2015). So, organizations which do not position IT as a primary key resource will soon be unable to compete with their competitors.

With the RBV framework, IT has attracted the interest of several researchers in resource management that related with creative performance (CP). However, this area of study is still inconclusive, and there are contradictions in results of research that has been carried out empirically. As IT has been found to have no significant effect against CP (Matin \& Sabagh, 2015; Mills \& Smith, 2011; Roldán, Real \& Sánchez Ceballos, 2018), this leaves room for a whole body of knowledge of research in the field of management. IT is a static asset, so dynamic induction is necessary to revive its role so that it can be effective in the organization. Previous research studies, in their focus, used a dynamic theory approach to create innovation and employ the concept of $\mathrm{OL}$ as support for converting IT into a resource that will ultimately have an impact on performance. In theory, OL has a strategic role in encouraging $C P$, but the track record of previous research shows that the $\mathrm{OL}$ theory still creates inconclusive results. OL itself is conventionally used to leverage the role of resources such as IT, but OL in several studies (Liao \& Wu, 2009; Santos-Vijande, López-Sánchez \& Trespalacios, 2012) has also failed to mediate the influence of IT on performance significantly.

$\mathrm{OL}$ has become the main attraction in a concept to dynamize organizational infrastructure, but when used as a mediation tool in some previous studies OL could not solve the gap. It takes more than just $\mathrm{OL}$, there needs to be a strong interaction value with cohesive ties such as "trust". This research offers trust-based active participation (TBAP) as a novelty to boost the role of IT in making CP more significant. TBAP is a derivative of the concept of the organizational learning theory. OL by (Cangelosi \& Dill, 1965) is a series of interactions involving adaptation at the individual level, group level, and relevant organizational levels to obtain information needed at these levels. The information-processing approach requires high cognitive learning from human learners through information-handling

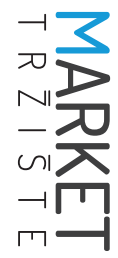




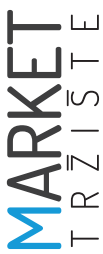

techniques (McLaughlin, Rossman \& McLeod, 1983). Deeper in cognitive learning, within the scope of the organization, cognitivism plays an important role in generating appropriate strategies for active participation in the learning process (Yilmaz, 2011). Value in the form of trust is built to flush the experiences of senior individuals, then convert them into the organization's repository of knowledge, up to the level of knowledge that is even tacit (Jain, Sandhu \& Goh, 2015; Khan, Breitenecker, Gustafsson \& Schwarz, 2015; Rutten, Blaas-Franken \& Martin, 2016; Swan, Trawick Jr., Rink \& Roberts, 1988). Trust-based OL will encourage the flexibility of organizational entities in their readiness to follow the flow of a dynamic environment, called readiness to change (RTC), where $\mathrm{RTC}$ will be a prerequisite for organizations to grow and survive amid competition. Therefore, this study is needed to empirically test TBAP as a grounded concept that will bridge and mediate the role of IT and its impact on performance, especially CP.

\section{RESEARCH AND HYPOTHESIS MODELS}

\section{Information Technology (IT)}

IT, as an infrastructure framework, builds on and facilitates the integration of the existing knowledge in an organization (Mills \& Smith, 2011). The definition of IT in the context of management science is that of a technology resource or asset, based on both hardware and software, that is empowered to integrate organizational entities to provide, create, transfer, store, and protect the flow of knowledge. As a crucial element in organizations, IT is needed to mobilize the potential resources that come from interpersonal communication relationships. The indicators used in explaining IT are technology integration-based relationships, technology implementation, and technology importance (Real, Leal \& Roldán, 2006).

\section{Creative Performance (CP)}

According to Edmonds, Weakley, Candy, Fell, Knott and Pauletto (2005), creativity is a concept of novelty, innovation, and originality. CP is the result of accumulating individual abilities in producing novel and useful ideas (Gumusluoglu \& Ilsev, 2009). So, strictly speaking, CP is the result of individual work in sparking novel ideas that can effectively and continuously bring about new product discovery. CP as a manifestation of target fulfillment, problem-solving creativity, fresh insight, effective design, and move-forward commitment (Gumusluoglu \& Ilsev, 2009) becomes the dependent variable in this study. Problem-solving creativity is the ability to process the potential so as to produce creative solutions that aim to solve urgent problems from different, original perspectives.

\section{Trust-Based Active Participation (TBAP)}

As a concept derived from the OL theory, TBAP is related to the process of creating an organizational knowledge repository. The learning process is a crucial aspect for finding the core of achievement and it requires support at the level of active participation of each organizational entity. Approaches to OL include culture learning, social learning, and cognitive learning (Dong, Hung \& Cheng, 2016; Fry, 2014; Yilmaz, 2011). Cognitive learning, in the form of sharing knowledge in groups is the exclusive value of the organization. The higher the trust, the better the personal cognitive relationships within the organization. The concept of trust becomes a value shared that distinguishes how explicit and tacit knowledge is spread, where tacit knowledge will be shared in the environments that truly have cohesiveness and trust. In its ontology, TBAP is a social cognitive concept of learning organizations with individual efficacy in fostering active participation in knowledge sharing in the social environment by emphasizing trust as a crucial value. Indicators representing trust-based active participation in this study are active participation, knowledge sharing, trust-based knowledge, and reliable groups (Ardichvili, Page \& Wentling, 2003; Jung, Choi, Lim \& Leem, 2002; Wenger, 2000; Zhang, Long, Wang \& Tang, 2015). 


\section{Readiness to Change (RTC)}

Change is inevitable in an organization; some unexpected pressures and incentives require the organization to make improvements, modifications, or variations in the structure, policies, and strategic approaches to organizational culture (Shah, Irani \& Sharif, 2017). As this change can affect every part of the organization, there is a need to be prepared to deal with such change. In its definition, according to Kirrane, Lennon, O'Connor and Fu (2017), readiness to change refers to organizational members' shared resolve to implement a change (change commitment) and shared belief in their collective capability to do so (change efficacy). Other than that, readiness to change (Rafferty, Jimmieson \& Armenakis, 2013) is a critical aspect of success of any initiative for changes. The RTC in this study was measured by looking at the level of readiness for technology acceptance, system understanding, system security, integration technology readiness, feature application, and idea design (Laseinde, Oluwafemi, Pretorius \& Oluwafemi, 2019).

\section{Human Capital Effectiveness (HCE)}

HCE is a concept derived from Bontis (Bontis, 2001; Bontis \& Fitz, 2002; Ramadan Bushra, Dahiyat Samer, Bontis \& Al-dalahmeh Mahmoud, 2017), who described it as an aggregate concept of human capital depletion and investment elaboration. The effectiveness of human capital contributes to the valuation of human resources. In some previous research, HCE typically has an impact on performance (Hashim, Osman \& Alhabshi, 2015). According to Augusto Felício, Couto and Caiado (2014), HCE is built on knowledge, experience, professional proficiency, and employee champions, all of which are inherent in individuals as agents of the organization (Ulrich, Brockbank, Younger \& Ulrich, 2012). HCE in this study consisted of employee champions, knowledge, and professional proficiency (Baron, 2011).

\section{IT and CP}

IT is used as an infrastructure instrument to support technology-based business activities in the organization, including the creation of supplier price lists, bookkeeping administration, virtual discussion facilities through video teleconferences, and finding creative content through the Internet. If the organization does not implement IT in its business, then the organization will not be able to survive because it will lack this creative strategic tool (Gold, Malhotra \& Segars, 2001). The strategic influence of IT on performance has been highlighted by various researchers (Abrego-Almazán, Sánchez-Tovar \& Medina-Quintero, 2017; Dzenopoljac, Alasadi, Zaim \& Bontis, 2018; Matin \& Sabagh, 2015; Mills \& Smith, 2011; Sung, 2015; Yunis et al., 2018). Some studies argue that IT can directly influence performance (Alaarj, Abidin-Mohamed \& Bustamam, 2016; Solberg \& Olsson, 2010; Garcia-Morales, Martín-Rojas \& Lardón-López, 2018; Imran, 2014). That statement is in line with a claim by Huang, Wu, Lu, and Lin (2016) that technology creation will trigger performance growth. The existence of such contradictions results in an inconclusiveness in studies of the influence of IT on performance that requires further exploration. Previous researchers (lqbal, Latif, Marimon, Sahibzada \& Saddam Hussain, 2018; Matin \& Sabagh, 2015) found that IT facilitates performance improvements in organizations, one of which is creativity, but such improvements cannot be direct. The ease with which technology can be imitated requires organizations to immediately get their creativity points in the current era of digital business. As infrastructure, IT requires elaboration with other concepts, so it is now seen as incapable of exerting direct influence on performance (Gomes \& Wojahn, 2017; José, Juan \& Silvia, 2018; Matin \& Sabagh, 2015; Rasel, 2016; Syarifah \& Fauziyah, 2017).

\section{IT and TBAP}

Virtual teamwork is used increasingly in organizations to make the most of employee competences and knowledge without geographical restrictions (Alsharo, Gregg \& Ramirez, 2017). This shows the magnitude of the influence of IT on the success of organizations that partic-

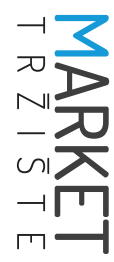


ipate actively in knowledge sharing (Alshurah, Zabadi, Dammas \& Dammas, 2018). Hislop (2002) outlined that IT has become a crucial aspect in the process of sharing objectivist perspectives on knowledge. This is in line with other studies (Kim \& Lee, 2006) which revealed that the use of IT applications affects employee knowledge-sharing capabilities while, on the other hand, IT encourages the creation of trust binding potential knowledge that benefits the organization (Alaarj et al., 2016; Sarmah, Rahman \& Kamboj, 2017; Smith, 2017; Wang \& Tseng, 2011). It has been well established that to gain valuable knowledge, trust between the sharing parties is needed. Trust is more difficult to build in organizations spanning a wide geographical area, especially global organizations and virtual firms (Ettlie, 2017). Therefore, IT plays an important role in facilitating trust-building necessary for the participation of every part of the organization in knowledge sharing. This is because the process of knowledge sharing generates explicit knowledge easily through IT and tacit knowledge requires trust in it. IT is seen as providing constructive support to the implementation of active participation in knowledge sharing based on trust (Falcone \& Castelfranchi, 2011; Göhlich, 2016).

\section{PICTURE 1: Conceptual model}

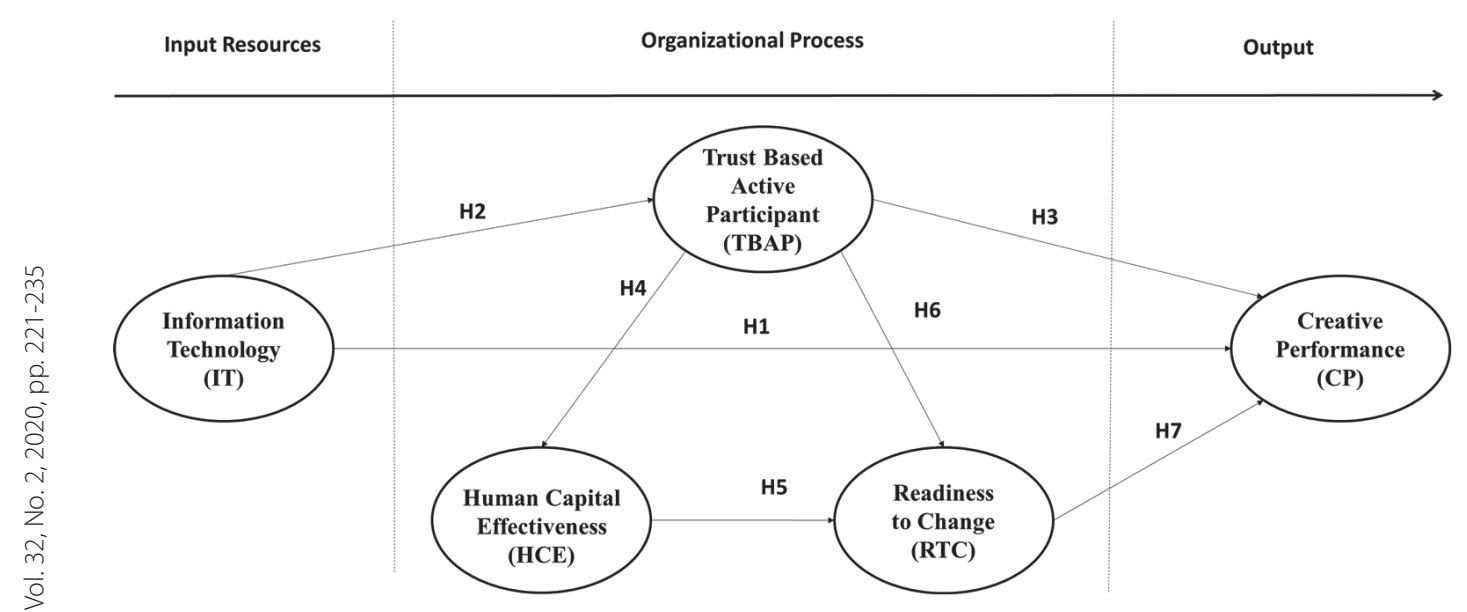

\section{TBAP and CP}

To transform organizations into knowledge societies, policymakers need to implement knowledge sharing (Alshurah et al., 2018). Some researchers found that active participation in knowledge sharing affects performance (Henttonen, 2016; Masa'deh, Obeidat \& Tarhini, 2016; Ozer \& Vogel, 2015). This is essential in boosting performance through active participation in sharing knowledge, and continuous knowledge sharing will open up the opportunities to connect ideas in order to find solutions to bottleneck problems in work life. In dynamic theory, fresh ideas can be bridged through the learning process that will enrich the birth of new ideas and become a foundation for CP. Active participation in sharing knowledge based on trust will enhance creativity because active participation will encourage collaboration surrounding knowledge in organizations for the development of new ideas (Dong, Bartol, Zhang \& Li, 2017; Kim \& Park, 2015; Mittal, 2015; Olaisen \& Revang, 2017; Zhang, Sun, Jiang \& Zhang, 2019).

Based on the description above, the conceptual model of the research is described as follows: 


\section{METHODOLOGY}

\subsection{Research objective}

This research was conducted by building on the novelty of the models offered to strengthen the role of IT in creating a significant impact on CP. As part of conventional infrastructure, IT requires another concept in its application to boost performance (Powell \& Dent, 1997). In other words, IT is a concept that cannot stand alone, so TBAP is expected to become a full mediator, acting as a bridge between IT and CP.

\subsection{Sampling and data collection}

The level of study is the organization. The respondents are managers who own creative SMEs in Indonesia that have been established for a minimum of three years. The characteristic of the sample is that it focused on fashion SMEs, emphasizing the design needs that must always be renewable. The data were collected through 220 questionnaires with a percentage return of 77.8\% (171 questionnaires), using a purposive sakoff, MacKenzie, Lee \& Podsakoff, 2003). Structural Equation Modelling (SEM) using the Analysis of Moment Structures (AMOS) was applied to process the 171 samples collected. According to Hair, Black, Babin, and Anderson (2009), the minimum number of samples sufficient for SEM is five times the number of indicators. With 15 indicators used in this study multiplied by 5 , the number of samples actually used has exceeded the minimum sample adequacy.

\subsection{Measurement}

The instrument in this study used a ten-point Likert scale, ranging from (1) strongly disagree and (10) strongly agree, to assess the responses provided in questionnaires. Data eligibility was checked through confirmatory factor analysis (CFA), validity, reliability, and goodness of fit tests on the full model. CFA is intended to test the unidimensionality of the dimensions forming latent variables. The following are the results of the CFA calculations that have met the requirements of each measurement indicator:

TABLE 1: Confirmatory factor analysis

\begin{tabular}{|c|c|c|c|c|c|c|c|c|c|}
\hline Variable & $\begin{array}{c}\text { Chi- } \\
\text { Square }\end{array}$ & $\begin{array}{c}\text { Prob } \geq \\
\mathbf{0 . 0 5}\end{array}$ & df & $\begin{array}{c}\text { CMIN / DF } \\
\mathbf{2 . 0 0}\end{array}$ & $\begin{array}{c}\text { RMSEA } \leq \\
\mathbf{0 . 0 8}\end{array}$ & $\begin{array}{c}\text { GFI } \\
\mathbf{0 . 9 0}\end{array}$ & $\begin{array}{c}\text { AGFI } \\
\mathbf{0 . 9 0}\end{array}$ & $\begin{array}{c}\text { TLI } \\
\mathbf{0 . 9 0}\end{array}$ & $\begin{array}{c}\text { CFI } \\
\mathbf{0 . 9 0}\end{array}$ \\
\hline IT & 4,042 & 400 & 4 & $1.011^{* *}$ & .008 & 991 & .964 & 1,000 & 1,000 \\
\hline TBAP & 1,729 & 421 & 2 & 865 & .000 & .995 & 967 & 1,005 & 1,000 \\
\hline HCE & 5,242 & 155 & 3 & 1,747 & .066 & 986 & .953 & .971 & 986 \\
\hline RTC & 7,249 & .510 & 8 & .906 & .000 & 986 & .964 & 1,002 & 1,000 \\
\hline CP & 7,935 & .94 & 4 & 1,984 & .076 & .983 & .936 & 959 & 984 \\
\hline
\end{tabular}

sampling approach. The potential of errors resulting from self-assessment could be reduced through the assistance of other officers helping the respondents fill the questionnaire. The answers by managers could be cross-checked with subordinates to also reduce misunderstanding of certain aspects of the questionnaire. Thus, this research uses procedural remedies technique to re-verify the responses and eliminate potential common method bias (Pod-
A validity test was used to ensure that each indicator can define each variable correctly, while the reliability test employed confirmed that the tools used to measure could produce the same results despite repeated testing (Hair et al., 2009), as shown in Table 2 below. 
TABLE 2: Validity and reliability tests

\begin{tabular}{|c|c|c|c|}
\hline Variable & Mean (Std. Deviation & AVE & CR \\
\hline IT & $6.68(1.62)$ & 0.50 & 0.75 \\
\hline TBAP & $6.33(1.45)$ & 0.50 & 0.60 \\
\hline HCE & $6.79(1.35)$ & 0.64 & 0.84 \\
\hline RTC & $7.15(1.32)$ & 0.60 & 0.90 \\
\hline CP & $7.43(1.04)$ & 0.60 & 0.87 \\
\hline
\end{tabular}

The validity level of the variable is evident from the standardized factor loading (see Figure 2) or from the average variance extract with a value of more than 0.05 . A variable is said to be reliable if $C R$ equals more than 0.6 and, based on the results in the table above, each variable has been confirmed valid and reliable.

TABLE 3: Discriminant validity

\begin{tabular}{|l|c|c|c|c|c|}
\hline & ITC & TBAP & HCE & RTC & CP \\
\hline ITC & $\mathbf{0 . 7 0 7}$ & & & & \\
\hline TBAP & 0.589 & $\mathbf{0 . 7 0 7}$ & & & \\
\hline HCE & 0.512 & 0.513 & $\mathbf{0 . 8 0 0}$ & & \\
\hline RTC & 0.403 & 0.350 & 0.434 & $\mathbf{0 . 7 7 5}$ & \\
\hline CP & 0.400 & 0.385 & 0.567 & 0.336 & $\mathbf{0 . 7 7 5}$ \\
\hline
\end{tabular}

The diagonal is a square root of AVE.

Table 3 shows that the square root value of AVE is higher than the construct correlation value of each variable. This proves that the variable can be accepted because it can distinguish the constructs in the model.

\section{DATA ANALYSIS AND RESULTS}

\subsection{Demographic and descriptive statistics}

Table 4 presents demographic information on the respondents. The sample used in this study consisted of 171 individuals, 121 of whom were women (70.76\%) and 50 men (29.24\%). The managerial sample is dominated by the millennial generation, aged under 30 years, accounting for as many as 71 respondents (41.52\%).

TABLE 4: Demographic information

\begin{tabular}{|l|l|c|}
\hline Variable & & Count \\
\hline \multirow{4}{*}{ Age } & less than 30 years old & 41.52 \\
\cline { 2 - 3 } & $31-40$ years old & 29.82 \\
\cline { 2 - 3 } & $41-50$ years old & 20.47 \\
\cline { 2 - 3 } & over 50 years old & 8.19 \\
\hline \multirow{4}{*}{ Gender } & male & 70.76 \\
\cline { 2 - 3 } & female & 29.24 \\
\hline \multirow{5}{*}{ Education } & junior high school & 45.03 \\
\cline { 2 - 3 } & senior high school & 51.46 \\
\cline { 2 - 3 } & bachelor degree & 3.51 \\
\hline
\end{tabular}

\subsection{Hypothesis testing}

Hypothesis testing based on the results of data processing was undertaken on a full model that has met the goodness of fit. The results are as follows:

FIGURE 2: Estimated structural model

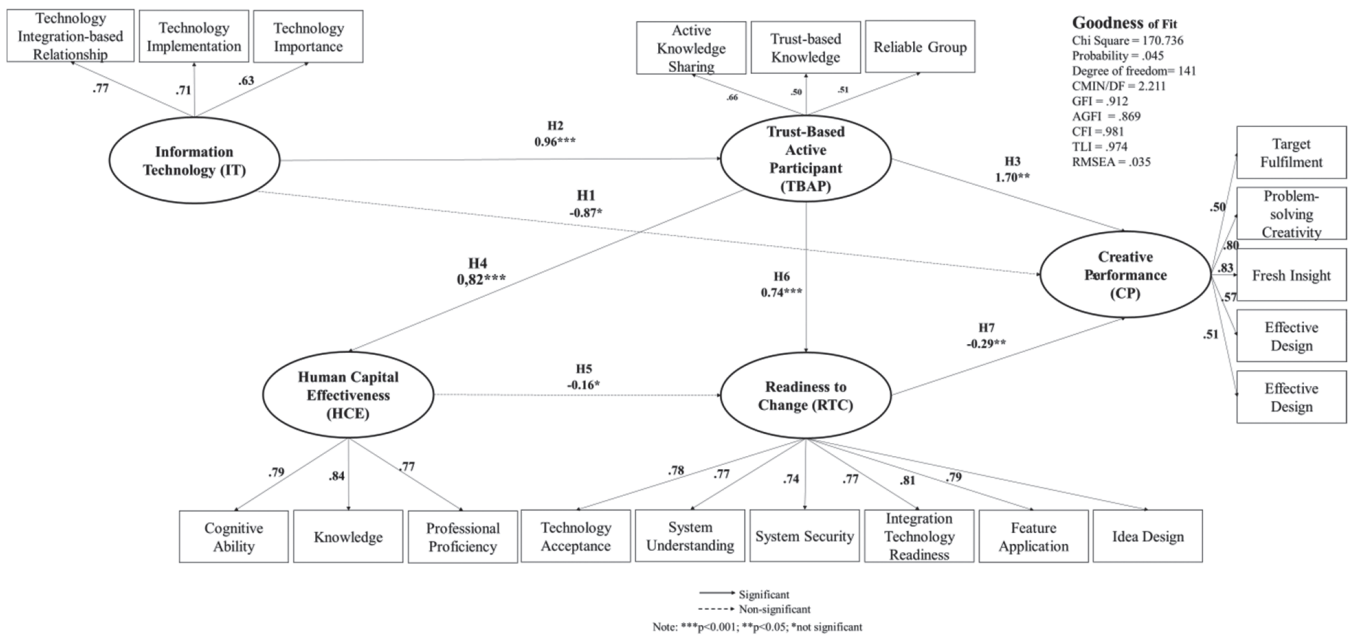


Figure 2 shows that, out of the seven hypotheses formulated, five were accepted ( $P<a$ alpha) and two hypotheses were rejected ( $P>$ alpha). Hypothesis 1 (H1) $(0.146>0.05)$, stating that IT has significant direct effect on $\mathrm{CP}$, was rejected. Hypothesis $\mathbf{2}(\mathbf{H 2})$ is accepted $\left({ }^{* * *}<0.001\right)$; it says that IT has a significant effect on trustbased active participation. Hypothesis $\mathbf{3}$ (H3) $(0.008<0.05)$, positing that trust-based active participation has a significant effect on $C P$, was also accepted as was Hypothesis 4 (H4) $\left({ }^{* *}<0.001\right)$, saying that trust-based active participation has a significant effect on human capital effectiveness. Hypothesis 5 (H5) (0.416>0.05), stating that human capital effectiveness has no significant effect on readiness to change, was rejected. Hypothesis 6 (H6) was accepted $\left(*^{* *}<0.001\right)$; it states that trust-based active participation has a significant effect on readiness to change. Hypothesis 7 (H7) $(0.024<0.05)$, saying that trust-based active participation has a significant effect on CP, was accepted. These results explain that trust-based active participation can become a full-mediation factor between IT and CP.

\subsection{Direct and indirect effect}

TABLE 5: Direct, indirect, and total effects of latent variables

\begin{tabular}{|l|c|c|c|}
\hline \multicolumn{1}{|c|}{$\begin{array}{c}\text { Latent } \\
\text { variables }\end{array}$} & $\begin{array}{c}\text { Direct } \\
\text { effect }\end{array}$ & $\begin{array}{c}\text { Indirect } \\
\text { effect }\end{array}$ & $\begin{array}{c}\text { Total } \\
\text { effect }\end{array}$ \\
\hline Effect on CP & & & \\
\hline H1: IT & -870 (ns) & 1,468 & 599 \\
\hline H3: TBAP & 1,701 & -.177 & 1,524 \\
\hline H7: RTC & -.288 & - & -.288 \\
\hline Effect on TBAP & & & \\
\hline H2: IT & .963 & - & .963 \\
\hline Effect on HCE & & & \\
\hline H4: TBAP & 817 & - & 817 \\
\hline Effect on RTC & & & \\
\hline H5: HCE & -.159 & - & $-.159(n s)$ \\
\hline H6: TBAP & 743 & -.130 & .613 \\
\hline
\end{tabular}

Table 5 shows that IT has no direct effect on $C P$, where there is no significance between the two.
The structural equation produced is $\mathrm{CP}=0.5991 \mathrm{~T}$ +1.524 TBAP - 0.288RTC. Conversely, IT can affect indirectly CP of 1,468. By considering the mediating effect, TBAP as a mediator influences $1,236\left(0.96^{*} 1.70\right)$. These results prove that TBAP has succeeded in carrying out its role as a bridge that fully mediates the influence of IT on CP significantly. On the other hand, it is known that HCE cannot support the influence of IT on CP because there is no significance for CP. Although HCE affects RTC, RTC has been proven empirically to have a negative influence on CP $(-.288)$, which means that there is an inverse function between the two.

\section{DISCUSSION OF THE RESULTS}

To increase $\mathrm{CP}$, in line with the emergence of a knowledge-based economy paradigm, an organization seeks to utilize IT. This research adds to the growing body of knowledge in management research by confirming that TBAP implementation is important for organizations to achieve maximum CP. Previous research (Abrego-Almazán et al., 2017; Gërguri-Rashiti, Ramadani, Abazi-Alili, Dana \& Ratten, 2017; Mills \& Smith, 2011; Yunis et al., 2018) has confirmed IT as a static tool that serves to drive other resources which have a direct role in performance. Nevertheless, IT support for the fulfillment of performance achievements cannot be underestimated, especially when it comes to the aspect of knowledge management.

In its capacity as infrastructure, IT helps in the process to absorb knowledge more easily and making it accessible anywhere and anytime. Currently, IT as an organizational infrastructure is widely used to convert ideas into creative products, investigate markets through business intelligence, capture impulse buying signals, conduct profitability assessments, support management decision, and facilitate market access. But well-organized OL tools are needed to dynamize IT. In utilizing IT, training and technology-enhanced learning are required 


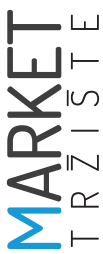

to create strategic value for organizations. A cohesive learning environment and growing trust between members of the organization are essential for inducing and sharing knowledge on the tacit level. As knowledge sharing at the tacit level is not accessible, trust in OL must be built. This may explain why, in prior studies, OL on its own was not able to fully bridge the gap. It should be highlighted that, without trust value within the scope of $\mathrm{OL}$, the meaning of learning is only on the surface, so it remains at an explicit level without touching the tacit knowledge. Induction at the explicit level does not have the capacity to solve complex bottlenecks problem. Without trust, there is no sharing of knowledge such as secret formulae, tricks, special techniques, or methods gained by senior employees through experience over many years while wrestling with the profession in which it is ingrained. In line with the organization's need to tap into the tacit knowledge of senior employees and convert it to a repository of organizational knowledge, the leader's role is to build the growth of trust between employees in the form of trust-based learning. Thus, the application of trust-based learning processes on the IT platform provides quality, credible, and useful knowledge input to organizations. Active participation through trust encourages team cohesiveness, strengthens solidity, integration, and work-life synergy within the team.

TBAP nurtured between personnel on a technology platform such as social media, webinars, teleconferences, online group chats, and so on, will help the release of tacit knowledge that contains new insights necessary for developing creativity in the organization. However, it cannot be denied that the readiness of personnel for the new technology offered is also influenced by the level of active participation in the sharing of knowledge related to the form, working manner, and function of the new technology itself. Therefore, this paper concludes that the RTC level of an organization in accepting technological change is influenced by the level of TBAP. Another empirical finding in the model is that the RTC contributes to improving HCE and con- firms the results of previous studies (e.g., Hsu, 2008; Papagapitos \& Riley, 2009; Yang, 2007). Although a study by Caliskan (2016) revealed the influence of HCE on the RTC, the findings of this study concluded otherwise, specifically, that the level of effectiveness in the use of human resources is not relevant to the level of readiness of the organization in accepting changes.

Organizational resources are divided into human resources and infrastructure. Therefore, with regard to HCE in the human context, which is still a static input and does not necessarily create an effect on performance, HCE requires another process to make it dynamic, such as organizational innovation (Hsu, 2007) and organizational governance. Moreover, individual preferences for status quo conditions as their comfort zone make this rational when HCE does not have a significant influence on RTC. RTC has a significant effect on CP. In this discussion, the RTC indicator refers to the system security indicator, feature application, and design idea as something that cannot be achieved in the short term, so it is true that the RTC negatively influences $C P$.

\section{CONCLUSION}

Based on the discussion above, it can be concluded that this research succeeded in building a new conceptual model by bringing in a new variable, namely TBAP, to encourage IT with a few to increasing CP maximally. The latest IT employed in facilitating active participation by organizations in trust-based learning processes can produce a commitment to creativity that can solve organizational problems and gain performance excellence.

Within the scope of the theory, this study provides two contributions to OL literature. Firstly, it provides a novelty model that aims to resolve the research gap that may be bridged by applying TBAP as the mediating concept that can significantly boost the role of IT in contributing to CP. Secondly, this research has contributed successfully to the body of knowledge that has 
been proven empirically, using SEM analysis tools, that TBAP is a deeper multiplication of OL and KM theories capable of fully mediating the relationship between IT and CP.

In a practical scope, there are several implications for organizations. First, given the importance of IT for running a business or organization, it is an aspect that must be continuously improved so that the organization continues to move with the times. Second, the implementation of TBAP can be done by forming a workgroup or business or organization and maintain it on the principle of cohesiveness that will foster a move-forward commitment from the personnel because it will provide a platform for them to develop and improve their creativity without any worries. On the other hand, trust ensures that each organization's personnel remain loyal, feel valued for their contribution, and trust their work partners will not become competitors in the future. Reciprocal relations in the induction of knowledge shared on the principle of trust have the potential and opportunity to produce new tacit knowledge. This would make it easier for organizations to foster individuals in entire organizations to maintain fresh insight, renewable ideas, effective design, and problem-solving results to be converted into inimitable products, as a prerequisite for survival in the knowledge-based economy paradigm.

The limitation of this study lies in the value of AGFI 0.869 < cut off (0.90, according to Hair et al. (2009)). However, that figure is still considered. Based on the results of the study, it is recommended to conduct further research related to the relationship between RTC and CP and include intervening variables that can encourage a positive influence between the two. The insignificant effect of HCE on CP provides additional scope for study in the search for mediation concepts, such as organizational innovation and organizational governance, that can enhance the role of HCE and contribute to its effect on CP.

\section{References}

1. Abrego-Almazán, D., Sánchez-Tovar, Y., \& Medina-Quintero, J. M. (2017). Influence of information systems in organizational performance. Contaduría y Administración, 62(2), 5-6.

2. Alaarj, S., Abidin-Mohamed, Z., \& Bustamam, U. S. B. A. (2016). Mediating Role of Trust on the Effects of Knowledge Management Capabilities on Organizational Performance. Procedia - Social and Behavioral Sciences, 235, 729-738.

3. Alsharo, M., Gregg, D., \& Ramirez, R. (2017). Virtual team effectiveness: The role of knowledge sharing and trust. Information \& Management, 54(4), 479-490.

4. Alshurah, M. S., Zabadi, A. M., Dammas, A. H., \& Dammas, D. H. (2018). Impact of organizational context and information technology on employee knowledge sharing. International Journal of Business and Management, 13(2), 194-207.

5. APJII (2018). Laporan Survei Penetrasi \& Profil Perilaku Pengguna Internet Indonesia. Retrieved from apjii.or.id

6. Ardichvili, A., Page, V., \& Wentling, T. (2003). Motivation and Barriers to Participation in Virtual Knowledge-Sharing Communities of Practice. Journal of Knowledge Management 7(1), 64-77.

7. Augusto Felício, J., Couto, E., \& Caiado, J. (2014). Human capital, social capital and organizational performance. Management Decision, 52(2), 350-364.

8. Baron, A. (2011). Measuring human capital. Strategic HR Review, 10(2), 30-35.

9. Bontis, N. (2001). Assessing knowledge assets: a review of the models used to measure intellectual capital. International Journal of Management Reviews, 3(1), 41-60.

10. Bontis, N., \& Fitz, J. (2002). Intellectual capital ROI: a causal map of human capital antecedents and consequents. Journal of Intellectual Capital, 3(3), 223-247. 
11. Caliskan, S. (2016). Are you ready for the global change? Multicultural personality and readiness for organizational change. Journal of Organizational Change Management, 29(3), 404-423.

12. Cangelosi, V. E., \& Dill, W. R. (1965). Organizational Learning: Observations Toward a Theory. Administrative Science Quarterly, 10(2), 175-203.

13. Cuevas-Vargas, H., Estrada, S., \& Larios-Gómez, E. (2016). The Effects of ICTs As Innovation Facilitators for a Greater Business Performance. Evidence from Mexico. Procedia Computer Science, 91, 47-56.

14. Dong, T-P., Hung, C-L., \& Cheng, N-C. (2016). Enhancing knowledge sharing intention through the satisfactory context of continual service of knowledge management systems. Information Technology \& People, 29(4), 807-829.

15. Dong, Y., Bartol, K. M., Zhang, Z-X., \& Li, C. (2017). Enhancing employee creativity via individual skill development and team knowledge sharing: Influences of dual-focused transformational leadership. Journal of Organizational Behavior, 38(3), 439-458.

16. Dzenopoljac, V., Alasadi, R., Zaim, H., \& Bontis, N. (2018). Impact of knowledge management processes on business performance: Evidence from Kuwait. Knowledge and Process Management 25(2), 77-87.

17. Edmonds, E. A., Weakley, A., Candy, L., Fell, M., Knott, R., \& Pauletto, S. (2005). The studio as laboratory: combining creative practice and digital technology research. International Journal of Human-Computer Studies, 63(4/5), 452-481.

18. Ettlie J. E. (2017). Trust, integrated information technology and new product success. European Journal of Innovation Management, 20(3), 406-427.

19. Falcone, R., \& Castelfranchi, C. (2011). Trust and relational capital. Computational and Mathematical Organization Theory, 17(4), 402-418.

20. Fry, M-L. (2014). Rethinking social marketing: towards a sociality of consumption. Journal of Social Marketing, 4(3), 210-222.

21. Garcia-Morales, V. J., Martín-Rojas, R., \& Lardón-López, M. E. (2018). Influence of social media technologies on organizational performance through knowledge and innovation. Baltic Journal of Management, 13(3), 345-367.

22. Gërguri-Rashiti, S., Ramadani, V., Abazi-Alili, H., Dana, L-P., \& Ratten, V. (2017). ICT, Innovation and Firm Performance: The Transition Economies Context. Thunderbird International Business Review, 59(1), 93-102.

23. Göhlich, M. (2016). Theories of Organizational Learning as resources of Organizational Education. In: A. Schröer, M. Göhlich, S. M. Weber \& H. Pätzold (eds.). Organization und Theorie (pp. 11-21). Berlin: Springer.

24. Gold, A. H., Malhotra, A., \& Segars, A. H. (2001). Knowledge Management: An Organizational Capabilities Perspective. Journal of Management Information Systems, 18(1), 185-214.

25. Gomes, G., \&Wojahn, R. M. (2017). Organizational learning capability, innovation and performance: study in small and medium-sized enterprises (SMES). Revista de Administração, 52(2), 163-175.

26. Gumusluoglu, L., \& Ilsev, A. (2009). Transformational leadership, creativity, and organizational innovation. Journal of Business Research, 62(4), 461-473.

27. Hair, J. F., Black, W. C., Babin, B. J., \& Anderson, R. E. (2009). Multivariate Data Analysis. New Jersey, NY: Pearson.

28. Hashim, K. F., \& Tan, F. B. (2015). The mediating role of trust and commitment on members' continuous knowledge sharing intention: A commitment-trust theory perspective. International Journal of Information Management, 35(2), 145-151.

29. Hashim, M. J., Osman, I., \& Alhabshi, S. M. (2015). Effect of Intellectual Capital on Organizational Performance. Procedia - Social and Behavioral Sciences, 211, 207-214. 
30. Henttonen, K. (2016). Knowledge sharing and individual work performance: an empirical study of a public sector organisation. Journal of Knowledge Management, 20(4), 749-768.

31. Hermawan, I., Sartono, N. G., \& Khakim, L. (2016). Open Innovation on Entrepreneurial Knowledge Intermediation Through Social Media Creative Development: A Case Study of Creative Cities in Indonesia. The Social Sciences, 11, 4378-4383.

32. Hislop, D. (2002). Mission impossible? Communicating and sharing knowledge via information technology. Journal of Information Technology, 17(3), 165-177.

33. Hsu, I. C. (2008). Knowledge sharing practices as a facilitating factor for improving organizational performance through human capital: A preliminary test. Expert Systems with Applications, 35(3), 1316-1326.

34. Hsu, S-H. (2007). Human Capital, Organizational Learning, Network Resources and Organizational Innovativeness. Total Quality Management \& Business Excellence, 18(9), 983-998.

35. Huang, K-E., Wu, J-H., Lu, S-Y., \& Lin, Y-C. (2016). Innovation and technology creation effects on organizational performance. Journal of Business Research, 69(6), 2187-2192.

36. Imran, M. K. (2014). Impact of knowledge management infrastructure on organizational performance with moderating role of KM performance: An empirical study on banking sector of Pakistan. Paper presented at the Information and Knowledge Management.

37. Iqbal, A., Latif, F., Marimon, F., Sahibzada, U. F., \& Saddam Hussain. (2018). From knowledge management to organizational performance: Modelling the mediating role of innovation and intellectual capital in higher education. Journal of Enterprise Information Management, 32(1), 36-59.

38. Jain, K. K., Sandhu, M. S., \& Goh, S. K. (2015). Organizational climate, trust and knowledge sharing: insights from Malaysia. Journal of Asia Business Studies, 9(1), 54-77.

39. José, R., Juan, R., \& Silvia, S. (2018). Antecedents and consequences of knowledge management performance: the role of IT infrastructure. Intangible Capital, 14(4), 518-535.

40. Jung, I., Choi, S., Lim, C., \& Leem, J. (2002). Effects of Different Types of Interaction on Learning Achievement, Satisfaction and Participation in Web-Based Instruction. Innovations in Education and Teaching International, 39(2), 153-162.

41. Khan, M. S., Breitenecker, R. J., Gustafsson, V., \& Schwarz, E. J. (2015). Innovative entrepreneurial teams: The give and take of trust and conflict. Creativity and Innovation Management, 24(4), 558573.

42. Kim, S-J., \& Park, M. (2015). Leadership, Knowledge Sharing, and Creativity: The Key Factors in Nurses' Innovative Behaviors. JONA: The Journal of Nursing Administration, 45(12), 615-621.

43. Kim, S., \& Lee, H. (2006). The Impact of Organizational Context and Information Technology on Employee Knowledge-Sharing Capabilities. Public Administration Review, 66(3), 370-385.

44. Kirrane, M., Lennon, M., O'Connor, C., \& Fu, N. (2017). Linking perceived management support with employees' readiness for change: the mediating role of psychological capital. Journal of Change Management, 17(1), 47-66.

45. Laseinde, T., Oluwafemi, I., Pretorius, J-H., \& Oluwafemi, J. (2019). The Role of Change Readiness in Determining Existing Relationship Between TQM Practices and Employee Performance. Paper presented at the International Conference on Applied Human Factors and Ergonomics.

46. Liao, S-H., \& Wu, C-C. (2009). The relationship among knowledge management, organizational learning, and organizational performance. International Journal of Business and Management, 4(4), 64-76.

47. Masa'deh, R. E., Obeidat, B. Y., \& Tarhini, A. (2016). A Jordanian empirical study of the associations among transformational leadership, transactional leadership, knowledge sharing, job performance, and firm performance: A structural equation modelling approach. Journal of Management Development, 35(5), 681-705. 
48. Matin, E. K., \& Sabagh, P. (2015). Effects of Knowledge Management Capabilities on Organizational Performance in Iranian Export Companies. Mediterranian Journal of Social Sciences, 6(2), 240-250.

49. McLaughlin, B., Rossman, T., \& McLeod, B. (1983). Second Language Learning: An Information-Processing Perspective. Language Learning, 33(2), 135-158.

50. Mills, A. M., \& Smith, T. A. (2011). Knowledge management and organizational performance: a decomposed view. Journal of Knowledge Management, 15(1), 156-171.

51. Mittal, S. (2015). Transformational leadership and employee creativity: Mediating role of creative self-efficacy and moderating role of knowledge sharing. Management Decision, 53(5), 894-910.

52. Olaisen, J., \& Revang, O. (2017). The dynamics of intellectual property rights for trust, knowledge sharing and innovation in project teams. International Journal of Information Management, 37(6), 583-589.

53. Ozer, M., \& Vogel, D. (2015). Contextualized Relationship Between Knowledge Sharing and Performance in Software Development. Journal of Management Information Systems, 32(2), 134-161.

54. Papagapitos, A., \& Riley, R. (2009). Social trust and human capital formation. Economics Letters, 102(3), 158-160.

55. Podsakoff, P. M., MacKenzie, S. B., Lee, J-Y., \& Podsakoff, N. P. (2003). Common method biases in behavioral research: A critical review of the literature and recommended remedies. Journal of applied psychology, 88(5), 879-903.

56. Powell, T. C., \& Dent, M. (1997). Information Technology as Competitive Advantage: The Role of Human, Business, and Technology Resources. Strategic Management Journal, 18(5), 375-405.

57. Rafferty, A. E., Jimmieson, N. L., \& Armenakis, A. A. (2013). Change readiness: A multilevel review. Journal of Management, 39(1), 110-135.

58. Ramadan Bushra, M., Dahiyat Samer, E., Bontis, N., \& Al-dalahmeh Mahmoud, A. (2017). Intellectual capital, knowledge management and social capital within the ICT sector in Jordan. Journal of Intellectual Capital, 18(2), 437-462.

59. Rasel, F. (2016). ICT, Complementary Firm Strategies and Firm Performance. Mannheim: Universität Mannheim.

60. Real, J., Leal, A., \& Roldán, J. (2006). Information Technology as A Determinant of Organizational Learning and Technological Distinctive Competencies. Industrial Marketing Management, 35, 505-521.

61. Roldán, J. L., Real, J. C., \& Sánchez Ceballos, S. (2018). Antecedents and consequences of knowledge management performance: the role of IT infrastructure. Intangible Capital, 14(4), 518-535.

62. Rutten, W., Blaas-Franken, J., \& Martin, H. (2016). The impact of (low) trust on knowledge sharing. Journal of Knowledge Management, 20(2), 199-214.

63. Sancez, V. B., Milan, M. J. C., \& Sahuquillo, C. A. (2018). A Study of The Value of ICT in Improving Corporate Performance: A Corporate Competitiveness View. Technological and Economic Development of Economy, 24(4), 1388-1407.

64. Santos-Vijande, M. L., López-Sánchez, J. Á., \& Trespalacios, J. A. (2012). How organizational learning affects a firm's flexibility, competitive strategy, and performance. Journal of Business Research, 65(8), 1079-1089.

65. Sarmah, B., Rahman, Z., \& Kamboj, S. (2017). Customer co-creation and adoption intention towards newly developed services: an empirical study. International Journal of Culture, Tourism and Hospitality Research, 11(3), 372-391.

66. Shah, N., Irani, Z., \& Sharif, A. M. (2017). Big data in an HR context: Exploring organizational change readiness, employee attitudes and behaviors. Journal of Business Research, 70, 366-378.

67. Smith, C. (2017). An Analysis Of Structural Social Capital And The Individual's Intention To Share Tacit Knowledge Using Reasoned Action Theory. Journal of Applied Business Research, 33(3), 475-488. 
68. Solberg, C. A., \& Olsson, U. H. (2010). Management orientation and export performance: the case of Norwegian ICT companies. Baltic Journal of Management, 5(1), 28-50.

69. Sung, T. K. (2015). Application of information technology in creative economy: Manufacturing vs. creative industries. Technological Forecasting and Social Change, 96, 111-120.

70. Swan, J. E., Trawick Jr., I. F., Rink, D. R., \& Roberts, J. J. (1988). Measuring dimensions of purchaser trust of industrial salespeople. Journal of Personal Selling \& Sales Management, 8(1), 1-10.

71. Syarifah, A. H., \& Fauziyah. (2017). Pengaruh Adopsi Teknologi Informasi pada Peningkatan Daya Siang Usaha Kecil dan Menengah Biro Sumber Daya Manusia (BSDM) Universitas Muhammadiyah Yogakarta, 8(2), 181-199.

72. Tippins, M. J., \& Sohi, R. S. (2003). IT competency and firm performance: is organizational learning a missing link? Strategic Management Journal, 24(8), 745-761.

73. Torkestani, M. S., Mazloomi, N., \& Haghighat, F. (2014). The Relationship between Information Systems Success, Organizational Learning and Performance of Insurance Companies. International Journal of Business and Social Science, 5(10), 125-132.

74. Ulrich, D., Brockbank, W., Younger, J., \& Ulrich, M. (2012). HR from the outside in: Six competencies for the future of human resources. New York, NY: McGraw Hill Professional.

75. Wang, T-L., \& Tseng, Y. F. (2011). A Study of the Effect on Trust and Attitude with Online Shopping. International Journal of Digital Society, 2(2), 433-440.

76. Wenger, E. (2000). Communities of Practice and Social Learning Systems. Organization, 7(2), 225246.

77. Yang, J. T. (2007). The impact of knowledge sharing on organizational learning and effectiveness. Journal of Knowledge Management, 11(2), 83-90.

78. Yilmaz, K. (2011). The Cognitive Perspective on Learning: Its Theoretical Underpinnings and Implications for Classroom Practices. The Clearing House: A Journal of Educational Strategies, Issues and Ideas, 84(5), 204-212.

79. Yunis, M., Tarhini, A., \& Kassar, A. (2018). The role of ICT and innovation in enhancing organizational performance: The catalysing effect of corporate entrepreneurship. Journal of Business Research, 88, 344-356.

80. Zhang, W., Sun, S. L., Jiang, Y., \& Zhang, W. (2019). Openness to Experience and Team Creativity: Effects of Knowledge Sharing and Transformational Leadership. Creativity Research Journal, 31(1), 62-73.

81. Zhang, X., Long, C., Wang, Y., \& Tang, G. (2015). The impact of employees' relationships on tacit knowledge sharing. Chinese Management Studies, 9(4), 611-625. 